\title{
EUROPEAN VECTOR OF SUSTAINABLE DEVELOPMENT OF ECONOMIC AND MANAGEMENT EDUCATION IN THE INSTITUTE OF ENGINEERING IN THE CONDITIONS OF RESTRUCTURING
}

\author{
Natalia Metelenko \\ Zaporizhzhia National University \\ $22 b$ Sobornyi ave., 69606, Zaporizhzhia, Ukraine \\ e-mail: natalia.metelenko@gmail.com \\ ORCID ID: https://orcid.org/0000-0002-6757-3124
}

\author{
Olena Trokhymets \\ Classic Private University \\ 70b Zhukovskyi str., 69602, Zaporizhzhia, Ukraine \\ e-mail:yelena.trohim@gmail.com \\ ORCID ID: https://orcid.org/0000-0001-7587-7948
}

\begin{tabular}{l}
\hline OPEN_Access $@$ doj \\
\hline Article history: \\
Received: June, 2020 \\
1st Revision: June, 2020 \\
Accepted: June, 2020 \\
\hline JEL classification: \\
125 \\
F53 \\
\hline
\end{tabular}

UDC:

378.3:339.944.2

\section{DOI:}

https://doi.org/10.331

08/sepd2020.01.003
Abstract. The study is based on the realities of the state and prospects for the development of the national higher education system during the period of active integration processes into the European Higher Education Space and the European Research Space. The analysis of the following aspects is carried out: the current state of the Ukrainian education system, the actions of the Ministry of Education and Science of Ukraine to develop cooperation with international organizations in various areas, in particular, to promote innovation and entrepreneurship in Ukraine, which is especially relevant for the industrial region - Zaporizhzhia region, which concentrates such strategic sectors of the Ukrainian economy as metallurgy, mechanical engineering, electricity.

It is emphasized that the legislation of Ukraine on education sets such a goal - development, effective functioning of the education quality assurance system in Ukraine, implementation of a constant and consistent process of improving the quality of education and it is noted that the development strategy of Zaporizhzhia National University (hereinafter ZNU) is to develop and consolidate leading positions aimed at training highly qualified specialists, development of scientific research, increasing the role of the innovative component in the activities of ZNU and its integration into the European and world educational space. It is proved that the restructuring of higher education institutions in Ukraine helps to increase the efficiency of their operation. The changes that took place in the process of joining the Zaporizhzhia State Academy of Engineering (hereinafter ZSIA) to ZNU and as a result of the creation of a structural unit - Engineering Educational and Scientific Institute (hereinafter EESI), which has a non-faculty structure and consists of fifteen departments of different areas of training, are analyzed.

The article substantiates the strategic advantages of the project of joining ZSIA to ZNU, which made it possible to diversify the educational programs of Bachelors and Masters educational levels in economics and management with the aim of curricula modern updating and further training of highly qualified specialists for industrial regions, in particular for industrial enterprises, in the fields of mechanical engineering, electric power and small and medium-sized businesses serving "large" industrial enterprises in the region. The results of work on improving the quality of higher education in EESI ZNU in the areas of non-formal and informal education, academic mobility, dual education, creating unique learning conditions for privileged categories of students and students with special needs, further integration of economic and managerial education in engineering education are analyzed.

Keywords: engineering teaching and research institute, university, academic mobility, non-formal education, informal education, European educational space.

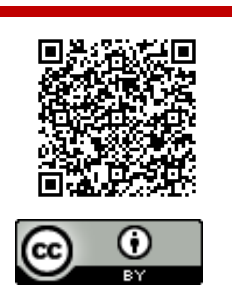

Метеленко Н. European vector of sustainable development of economic and management education in the institute of engineering in the conditions of restructuring [Електронний ресурс] / Наталія Метеленко, Олена Трохимець // Соціально-економічні проблеми і держава. - 2020. - $\quad$ Вип.1(22). доступу: http://sepd.tntu.edu.ua/images/stories/pdf/2020/20mngcor.pdf

This open access article is distributed under a Creative Commons Attribution (CC-BY) 4.0 license. 


\section{Statement of the problem.}

The Law of Ukraine «On Higher Education» [1] provides a definition of «higher education», such as it is «... a set of systematized knowledge, skills and practical skills, ways of thinking, professional, ideological and civic qualities, moral and ethical values, other competencies, acquired in a higher education institution (scientific institution) in the relevant field of knowledge with a certain qualification at the levels of higher education, which in terms of complexity are higher than the level of complete general secondary education». Legislation of Ukraine on higher education, along with the law «On Higher Education», is based on the Constitution of Ukraine, includes laws of Ukraine «On Education», «On scientific and scientifictechnical activities» and other regulations, as well as international treaties of Ukraine, which are concluded in the manner prescribed by law and allow for the integration of the national higher education system into the European Higher Education Space and the European Research Space. The structure of higher education in Ukraine is built in accordance with the structure of education in developed countries, which is defined by UNESCO, the UN and other international organizations.

Thus, along with other measures of integration of the national higher education system into the European educational space, on February 24, 2020 the Ministry of Education and Science of Ukraine signed a Memorandum with the innovation park UNIT. City, which provides for joint organization of events to raise awareness about modern information technologies, entrepreneurial culture, startup ecosystem, etc. The key areas of cooperation are to support partnerships with international organizations that are ready to promote the development of innovation and entrepreneurship in Ukraine [2].

The purpose of the study is to substantiate the strategic guidelines of the European vector of sustainable development of economic and management education in the Engineering Educational and Research Institute in the context of restructuring.

\section{Analysis of recent research and publications.}

Strategic issues of sustainable development of higher education institutions, integration of the national higher education system into the European educational space, improving the quality of higher education in the direction of training highly qualified specialists are the subject of study of both foreign and Ukrainian scientists, including V. H. Kremen, Ya. Ia. Boliubash, O. V. Spivakovskyi, B. M. Andrushkiv, S. A. Shmelova, F. H. Vashchuk, M. Z. Zghurovskyi, V. P. Andrushchenko and other prominent scholars, who rightly believe and insist that higher education is directly related to the system of national interests and national security.

\section{Unsolved aspects of the problem.}

The national system of higher education is the most important part of the formation of the State's citizen's consciousness and provides the formation of an educated creative personality. Building a system of higher education today requires all participants to ensure the quality of the educational process to address a number of modern issues arising in the context of its reform in the direction of European integration processes, such as strengthening Ukrainian statehood, cultural and spiritual development of the Ukrainian community. 


\section{Main material exposition.}

The article 41 of the Law of Ukraine «On Education» emphasizes that the purpose of building and functioning of education quality assurance in Ukraine is: guaranteeing the quality of education, building public confidence in the system and educational institutions, education authorities, continuous and consistent improvement of education, assistance education and other subjects of educational activity in improving the quality of education. Such fundamental targets are the basis of the development strategy of Zaporizhzhia National University, a structural unit of which is the Engineering Educational and Scientific Institute. Thus, «the development strategy of Zaporizhzhia National University is to develop and consolidate by 2022 the leading positions aimed at training highly qualified specialists, development of research, strengthening the role of innovation in ZNU and its integration into the European and world educational space...» [3].

The merger (by joining) of the Zaporizhzhia State Engineering Academy to the Zaporizhzhia National University took place in November 2018. As a result of the restructuring, a structural subdivision was created - the Engineering Educational and Scientific Institute, which has a non-faculty structure and consists of fifteen departments of various fields of training in the following specialties: economics; accounting and taxation; finance, banking and insurance; management; entrepreneurship, trade and exchange activities; software engineering; branch mechanical engineering; metallurgy; electric power, electrical engineering and electromechanics; heat energy; hydropower; automation and computer-integrated technologies; micro- and nanosystem technology; electronics; environmental protection technologies; architecture and urban planning; construction and civil engineering; civil security; public administration.

This educational project aims to:

- increasing the number of branches of knowledge, specialties, educational programs on preparation of highly skilled experts in the ZNU for the industrial regions of South-Eastern Ukraine;

- improving the quality of creative and research activities by supporting interfaculty cooperation in the field of research in order to find synergies and implement joint large projects;

- development of dual education in the Zaporizhzhia industrial region in order to further build an innovative society and strengthen the proper link between the labor market and the higher education system;

- further integration of higher education in Ukraine into the European educational and scientific space based on the implementation of the principles of student-centered approach; scientific validity; readiness for systemic changes; realism and consistency in the direction of strengthening academic integrity at the university;

- increasing the types, forms of academic mobility and granting the right to participate in academic mobility programs to all participants in the educational process in order to further internationalize higher education through the convergence of different countries' approaches to education, which is a necessary condition for common educational space;

- expanding the use of non-formal and informal education in order to promote the democratization of society, the comprehensive development of civil society, civic activism and leadership; solving the problem of leisure for young people and the elderly, which, taken together, allows formal education to respond flexibly and quickly to the needs of the labor 
market and services, meeting the requirements of students, workers and employers and complementing educational proposals.

Thus, it is clear that the unification of two higher education institutions in the Zaporizhzhia Region, the active internationalization of higher education at the EESI ZNU during 2019 - 2020 motivates the comprehensive convergence of national educational systems, ensures their complementarity, transformation of higher education in general on the world social system.

In the direction of realization of the strategic goal of uniting the above-mentioned institutions of higher education in November 2018, educational programs were diversified in ZNU-related specialties (Table 1), both at the bachelors and masters level.

Table 1. Diversification of educational programs of specialties of economics and management and administration fields of study (level I - bachelor) of ZNU and Engineering Educational and Scientific Institute of ZNU

\begin{tabular}{|c|c|}
\hline Zaporizhzhia National University & Engineering educational and scientific institute of ZNU \\
\hline \multicolumn{2}{|c|}{ LEVEL - BACHELOR } \\
\hline \multicolumn{2}{|c|}{071 - Accounting and taxation } \\
\hline Accounting and audit & Taxation, accounting, control in enterprise management \\
\hline \multicolumn{2}{|c|}{072 - Finance, banking and insurance } \\
\hline Finance and credit & State finances and business structures \\
\hline \multicolumn{2}{|c|}{073 - Management } \\
\hline Management of foreign economic activity & Industrial Management \\
\hline $\begin{array}{c}\text { Management of organizations and } \\
\text { administration }\end{array}$ & \\
\hline Management of hotel, resort and tourist service & \\
\hline Management of international business & \\
\hline \multicolumn{2}{|c|}{076 - Entrepreneurship, trade and exchange activities } \\
\hline Entrepreneurship and commercial logistics & Economy of the enterprise \\
\hline Agrobusiness & \\
\hline \multicolumn{2}{|c|}{051 - Economics } \\
\hline Economic Cybernetics & Information economy \\
\hline International Economics & \\
\hline Economics and management of the land market & \\
\hline Personnel management and labor economics & \\
\hline \multicolumn{2}{|c|}{281 - Public management and administration } \\
\hline Public management and administration & Public administration \\
\hline
\end{tabular}

Based on the results of educational programs diversification, the EESI ZNU directed the process of curriculum formation in the direction of training specialists in accounting, finance, economics, management for industrial regions, in particular for metallurgical, machinebuilding, electric power and small and medium-sized enterprises which serve «large» industrial enterprises in the Region.

The actualization of educational programs of economic and managerial education at the EESI ZNU allowed carrying out integration processes into the educational space of engineering specialties, such as:

- the practice of obtaining higher education by students is spreading at the same time in engineering and in the economics and management specialties, actively implementing European standards in the learning process, which fills the educational process with dynamics and ensures their own development;

- the scientific community of the EESI ZNU organizes scientific and practical conferences, round tables, which have the status of international events and contribute to improving the quality of educational services; 
- modern types and forms of academic mobility are introduced (programs of student internships and internships of teaching staff); non-formal education (in the structural unit of Zaporizhzhia Hydropower Vocational College of ZNU, in the State Tax Service in Zaporizhzhia); of informal education, i.e. not institutionalized self-education, which forms the professional competencies of a specialist in the integration of non-formal and informal education;

- the program of development of the student-centered approach at rendering of educational services to privileged categories of students (participants of anti-terrorist operation, children - orphans, etc.) and students with special needs which is based on adequate support of the student and teacher support.

Zaporizhzhia Region is an industrial region in which enterprises operate mainly in the field of mechanical engineering and metallurgy. These enterprises, which have been budgetgenerating for a long time, include PJSC «Zaporizhstal», PJSC «Zaporizhkoks», PJSC «Motor Sich», PJSC «Abrasive Plant», PJSC «Zaporizhzhia Valve Plant», PJSC «Zaporizhzhia Iron Ore Plant», PJSC «Ukrainian Graphite», PJSC «Dniprospetsstal», CT «Zaporizhzhia High Voltage Equipment Plant», PJSC «Zaporizhtransformator», PJSC «ZAZ», PJSC «Pivdentranssenergo» etc.

That is, the Zaporizhzhia Region is saturated with large industrial enterprises, due to the efficient functioning of which urban development is carried out, the city infrastructure is updated, the social sphere is developed, jobs are created and the welfare of the region's population increases. However, in the last 20 years in the Zaporizhzhia Region there had been negative structural changes, which eventually led to a predominant increase in the share of cheap raw materials with low added value and a significant decrease in the share of high-tech economically many times more profitable products with high added value. That is, the engineering industry was gradually collapsing and its products became increasingly uncompetitive in both domestic and foreign markets. However, some metallurgical enterprises in the region preserved their markets and operate successfully, but these are enterprises that produce products that are used in international markets as raw materials for high-tech industries [4, p. 152].

It is clear that in such difficult economic conditions there is a need to annually update the content of educational programs and adjust curricula. In order to improve the quality of educational services at the second educational level of training (Master's Degree) (Table 2), annual review of educational programs takes place (their improvement) to ensure their compliance with these goals, as well as the needs of students, stakeholders, society in general.

According to the results of the improvement of Master's educational programs in 2020, the following disciplines were included in the curricula for Master's degree in economics and management (Table 2): legal support of public administration (281); political consciousness of employees of public authorities and local self-government (281); potential management of business structures (076); entrepreneurship in the economic development of society (076); economics and organization of small business (076); architecture of modern Web-services (051); training course on the effectiveness of IT projects (051); accounting and taxation of small businesses (071); quality management system at an industrial enterprise (073); international law in foreign economic activity in industry (073); market pricing in industry (073); management of financial security of the state and business (072); legal support of business activity in Ukraine and EU countries (072); management of financial resources of the state and territorial communities (072). The proposed changes are focused at market needs; take into account the European experience of the leading universities of Poland and Slovakia 
in the formation of curricula for educational programs in economics and management fields of study. That is, we realize that the Master Degree student or graduate must know the list of the most important problems and tasks in the main areas of business [5, p. 108] and in the process of learning to get answers to key questions about their solution.

Table 2. Diversification of educational programs of specialties of economics and management and administration fields of study (level II - master) of ZNU and Engineering educational and scientific institute of ZNU

Zaporizhzhia National University $\quad$ Engineering educational and scientific institute of ZNU

\begin{tabular}{|c|c|}
\hline \multirow{2}{*}{\multicolumn{2}{|c|}{$\begin{array}{c}\text { LEVEL - MASTER'S } \\
071 \text { - Accounting and taxation }\end{array}$}} \\
\hline & \\
\hline Accounting and audit & Accounting, analysis, control in enterprise management \\
\hline & Taxation \\
\hline \multicolumn{2}{|c|}{072 - Finance, banking and insurance } \\
\hline Finance and credit & Public and local finance management \\
\hline & Financial management of business structures \\
\hline \multicolumn{2}{|c|}{073 - Management } \\
\hline Management of foreign economic activity & Industrial management \\
\hline $\begin{array}{l}\text { Management of organizations and } \\
\text { administration }\end{array}$ & \\
\hline $\begin{array}{l}\text { Management of educational, cultural and } \\
\text { sports institutions }\end{array}$ & \\
\hline Logistics & \\
\hline Business administration & \\
\hline Project management & \\
\hline Financial and economic security management & \\
\hline \multicolumn{2}{|c|}{076 - Entrepreneurship, trade and exchange activities } \\
\hline Agrobusiness & Business economics and business management \\
\hline \multicolumn{2}{|c|}{051 - Economics } \\
\hline Economic Cybernetics & Information economy \\
\hline International Economics & \\
\hline $\begin{array}{c}\text { Economics and management of the land } \\
\text { market }\end{array}$ & \\
\hline Personnel management and labor economics & \\
\hline \multicolumn{2}{|c|}{281 - Public management and administration } \\
\hline Public management and administration & Public administration \\
\hline
\end{tabular}

The development of the dual form of education is especially important for the industrial region, the main task of which is to eliminate the shortcomings of traditional forms and methods of training future professionals and bridge the gap between theory and practice, education and production. In this regard, a striking example of the development of dual education in Zaporizhzhia is the establishment of joint work of the EESI ZNU with a group of «METINVEST» companies.

In the context of the ongoing restructuring at the EESI ZNU, the provision of educational services, in our opinion, should be based on the following principles:

- ensuring and improving the quality of management activities, building a modern quality management system in the EESI ZNU in close cooperation with certified experts of the National Agency for Higher Education Quality Assurance, who are employees of the EESI ZNU;

- formation and support of social cohesion of the staff of the Institute, preservation of its educational traditions;

- growing demand for skills and competencies of specialists of engineering specialties of the EESI ZNU and specialists of economic and managerial direction through ensuring the European quality of educational services in the EESI ZNU; 
- student-centered approach to the organization of the educational process and personal development of students; preparing students for active citizenship and future careers; EESI ZNU;

- development of digital learning technologies in all educational programs of the

- building a developed own knowledge base of EESI ZNU, stimulating research and innovation;

- development of the EESI ZNU educational programs on the principle of complementarity;

- application of exemplary practices in the relevant areas of educational activities of the EESI ZNU;

- prevention of intolerance or discrimination against students and teachers;

- involvement of external parties in ensuring the quality of educational services in the EESI ZNU;

- development of a policy for providing educational services to privileged categories of students;

- development of the cycle of training in educational programs (school - college institute) - a step-by-step approach;

- ensuring and motivating the professional development of the teaching staff;

- ensuring the availability of adequate and publicly available educational resources for students of different categories (mature students, part-time students, employed students, foreign students, students with disabilities).

Mechanism of implementation of certain principles, on which the European vector of sustainable development of economic and managerial education in the EESI ZNU is based, is presented in the Table 3.

Table 3. The mechanism of the European vector of sustainable development principles realization of the Engineering educational and scientific institute of ZNU

\begin{tabular}{|c|c|c|}
\hline № & Principle & The mechanism of the principle implementation \\
\hline 1 & 2 & 3 \\
\hline 1 & $\begin{array}{l}\text { Ensuring and improving the quality } \\
\text { of management activities, building a } \\
\text { modern quality management } \\
\text { system in EESI in close cooperation } \\
\text { with certified experts of the } \\
\text { National Agency for Higher } \\
\text { Education Quality Assurance, who } \\
\text { are employees of the EESI ZNU }\end{array}$ & $\begin{array}{l}\text { optimization of management and rationalization of interaction } \\
\text { between the heads of all structural units of the EESI, elimination of } \\
\text { duplication of functions, personal responsibility of each head for the } \\
\text { final results of its structural unit, optimization of document flow in } \\
\text { EESI and in the system «EESI - ZNU» and analysis of effective } \\
\text { collection system making management decisions by the } \\
\text { management of ZNU; improving communications with structural } \\
\text { units of ZNU }\end{array}$ \\
\hline 2 & $\begin{array}{l}\text { Formation and support of social } \\
\text { cohesion of the staff of the institute, } \\
\text { preservation of its educational } \\
\text { traditions }\end{array}$ & $\begin{array}{l}\text { team cohesion based on the desire to achieve the strategic goal of } \\
\text { EESI, team cohesion based on scientific interests and their further } \\
\text { development, development of educational traditions of metallurgy, } \\
\text { energy, construction, information technology, economics and } \\
\text { management, further development of scientific schools; support for } \\
\text { establishing and restoring partnerships with leading institutions of } \\
\text { higher education of Ukraine (in particular, in terms of scientific } \\
\text { interests) }\end{array}$ \\
\hline 3 & $\begin{array}{l}\text { Growing demand for skills and } \\
\text { competencies of specialists of } \\
\text { engineering specialties of EESI and } \\
\text { specialists of economic and } \\
\text { managerial direction through } \\
\text { ensuring the European quality of } \\
\text { educational services in the EESI }\end{array}$ & $\begin{array}{l}\text { annual renewal of disciplines of EESI ZNU educational programs in } \\
\text { accordance with today's requirements, cooperation with leading } \\
\text { universities of Eastern and Central Europe in the direction of further } \\
\text { development of double degree programs in all (without exception) } \\
\text { the EESI ZNU specialties, creation of combined programs based on } \\
\text { existing educational programs nature (at the request of employers); } \\
\text { expanding the scope of international educational activities }\end{array}$ \\
\hline
\end{tabular}




\begin{tabular}{|c|c|c|}
\hline & & Continuation of the table 3 \\
\hline 1 & 2 & 3 \\
\hline 4 & $\begin{array}{l}\text { Student-centered approach to the } \\
\text { organization of the educational } \\
\text { process and personal development } \\
\text { of students; preparing students for } \\
\text { active citizenship and future } \\
\text { careers }\end{array}$ & $\begin{array}{l}\text { introduction of approaches aimed at encouraging students to } \\
\text { actively participate in the creation of the educational process } \\
\text { (working in groups working with each other; involving employers in } \\
\text { conducting classes, etc.); and their needs, regular evaluation and } \\
\text { adjustment of ways of presenting the material, proper mentoring, } \\
\text { support from the teacher, the development of mutual respect } \\
\text { between student and teacher, the development of educational work } \\
\text { with students; formation of students' abilities for self-development } \\
\text { and self-improvement; providing them with conditions for self- } \\
\text { realization; taking into account the individual directions and } \\
\text { abilities of students }\end{array}$ \\
\hline 5 & $\begin{array}{l}\text { Development of digital learning } \\
\text { technologies in all the EESI ZNU } \\
\text { educational programs }\end{array}$ & $\begin{array}{l}\text { ensuring the improvement of digital literacy as a result of the use of } \\
\text { digital technologies in education, the inclusion of disciplines of } \\
\text { applied information technology in all educational programs of the } \\
\text { EESI ZNU, the formation of critical thinking in the educational } \\
\text { process of students, digital literacy and avoidance of plagiarism, } \\
\text { online discussions of students with employers digital literacy; } \\
\text { directing teaching activities to the use of digital technologies and } \\
\text { motivating students and teachers to digital innovations }\end{array}$ \\
\hline 6 & $\begin{array}{l}\text { Building a developed own } \\
\text { knowledge base of the EESI ZNU, } \\
\text { stimulating research and innovation }\end{array}$ & $\begin{array}{l}\text { accumulation of information on the scientific achievements of the } \\
\text { institute for the last } 20 \text { years in the areas of research and } \\
\text { specialties; preparation of its own knowledge base in engineering } \\
\text { and economic - management in order to gradually create scientific } \\
\text { schools, interaction (contractual work) with employers in the region } \\
\text { to use scientific achievements of the EESI ZNU; revival of the school } \\
\text { of scientific innovators in order to stimulate research and } \\
\text { innovation by young scientists (succession of generations) }\end{array}$ \\
\hline 7 & $\begin{array}{l}\text { Development of the EESI ZNU } \\
\text { educational programs on the } \\
\text { principle of complementarity }\end{array}$ & $\begin{array}{l}\text { ensuring the diversification of educational programs in accordance } \\
\text { with today's requirements; ensuring the differentiation of the } \\
\text { educational process (taking into account the interests of } \\
\text { participants in the educational process, the conscious formation of } \\
\text { directions of the educational process); integration of educational } \\
\text { programs of engineering directions and economic - managerial } \\
\text { direction; individualization of educational programs (taking into } \\
\text { account and development of individual features of students in the } \\
\text { process of teaching and education); informatization of education } \\
\text { through the content of educational programs of engineering and } \\
\text { economic - managerial directions }\end{array}$ \\
\hline 8 & $\begin{array}{l}\text { Application of exemplary practices } \\
\text { in the relevant areas of educational } \\
\text { activities of the EESI ZNU }\end{array}$ & $\begin{array}{l}\text { The use of information and communication technologies (ICT) in the } \\
\text { educational process of EESI to increase the information competence } \\
\text { of teachers and students; support and continuous improvement of } \\
\text { the professional level of teachers in the use of ICT; development of } \\
\text { interuniversity cooperation in all scientific activities of the EESI } \\
\text { ZNU; development of cooperation with leading European } \\
\text { universities (in the field of economics and management); } \\
\text { development of feedback (active student participation in the } \\
\text { learning process) for each educational program, the development of } \\
\text { interdisciplinary links within each educational program; effective } \\
\text { interaction of the EESI ZNU scientific community with students in } \\
\text { academic and industrial conditions }\end{array}$ \\
\hline 9 & $\begin{array}{l}\text { Prevention of intolerance or } \\
\text { discrimination against students and } \\
\text { teachers }\end{array}$ & $\begin{array}{l}\text { development of mutual respect in the relationship between student } \\
\text { and teacher; promoting students in their academic careers, further } \\
\text { introduction of flexible teaching and learning methods, creating } \\
\text { conditions for professional development of teaching staff, } \\
\text { strengthening the link between education and research in the } \\
\text { relationship between students and teachers, encouraging the use of } \\
\text { innovative teaching methods in direct collaboration with students }\end{array}$ \\
\hline
\end{tabular}




\begin{tabular}{|c|c|c|}
\hline & & Continuation of the table 3 \\
\hline 1 & 2 & 3 \\
\hline 10 & $\begin{array}{l}\text { Involvement of external parties } \\
\text { in ensuring the quality of } \\
\text { educational services in the EESI } \\
\text { ZNU }\end{array}$ & $\begin{array}{l}\text { involvement of employers (industrialists, manufacturers) in the } \\
\text { processes of modernization of educational programs, involvement of } \\
\text { partner universities to participate in the improvement of the } \\
\text { educational process in the EESI ZNU, involvement of employers } \\
\text { (government agencies) to participate in the organization of the } \\
\text { educational process in the EESI ZNU; involvement of the EESI ZNU } \\
\text { graduates in the organization of monitoring the quality of educational } \\
\text { services in the EESI ZNU, involvement of stakeholders in rethinking the } \\
\text { essence and role of educational services in the EESI ZNU, involvement } \\
\text { in the process of teaching applied disciplines to practicing professionals } \\
\text { on a voluntary basis and on an employment contract }\end{array}$ \\
\hline 11 & $\begin{array}{l}\text { Development of a policy for } \\
\text { providing educational services } \\
\text { to privileged categories of } \\
\text { students }\end{array}$ & $\begin{array}{l}\text { development of forms of distance education, further cooperation with } \\
\text { international scientific communities, development of individual } \\
\text { approaches to the provision of educational services for privileged } \\
\text { categories of students in the Moodle system, activities aimed at } \\
\text { improving computer literacy of students of various privileged } \\
\text { categories, use of online textbooks for educational services privileged } \\
\text { categories, the use of ZOOM - a resource for group classes with } \\
\text { privileged categories }\end{array}$ \\
\hline 12 & $\begin{array}{l}\text { Development of the cycle of } \\
\text { training in educational programs } \\
\text { (school - college - institute) - a } \\
\text { step-by-step approach }\end{array}$ & $\begin{array}{l}\text { audit of specialties that are the part of the EESI ZNU, and may be } \\
\text { participants in the «full cycle of training», the restoration of contractual } \\
\text { relations with schools, vocational education institutions, colleges in } \\
\text { order to create (restore) the «full cycle of training»; "full cycle of } \\
\text { training» for educational programs of the EESI ZNU; involvement of } \\
\text { European educational institutions in the program «full cycle of } \\
\text { training», cooperation with local governments on the resumption of the } \\
\text { program «full cycle of training» }\end{array}$ \\
\hline 13 & $\begin{array}{l}\text { Ensuring and motivating the } \\
\text { professional development of the } \\
\text { teaching staff }\end{array}$ & $\begin{array}{l}\text { restoration (renewal) of contractual relations with institutions of } \\
\text { higher education in all areas of training in the EESI ZNU on research } \\
\text { and teaching internships, intensification of contractual work on } \\
\text { international internships for teachers, resumption and intensification } \\
\text { of work on internships for teachers of institutions of higher education } \\
\text { of Ukraine in the EESI ZNU; development of a mechanism of personal } \\
\text { responsibility (management) for the development of the direction of } \\
\text { internship of teaching staff }\end{array}$ \\
\hline 14 & $\begin{array}{l}\text { Ensuring the availability of } \\
\text { adequate and publicly available } \\
\text { educational resources for } \\
\text { students of different categories } \\
\text { (mature students, part-time } \\
\text { students, employed students, } \\
\text { foreign students, students with } \\
\text { disabilities) }\end{array}$ & $\begin{array}{l}\text { continuation of the restoration of the material and technical base of the } \\
\text { EESI ZNU (subject to the availability of such expenditure items in the } \\
\text { budget of ZNU), audit and effective use of the existing laboratory base } \\
\text { of the EESI ZNU for the development of educational programs, re- } \\
\text { equipment of the EESI ZNU laboratory fund to ensure the educational } \\
\text { process etc.), search for sources of funding to improve the material and } \\
\text { technical base of the EESI }\end{array}$ \\
\hline
\end{tabular}

Thus, the process of forming of the European vector of sustainable development of economic and managerial education at the EESI ZNU is aimed at creating an attractive and competitive higher education system integrated into the European Higher Education Space and the European Research Space; it takes into account changes in macroeconomic and social conditions of the EESI ZNU functioning; based on the analysis of the internal and external environment; focused on the innovative development of the educational process in the EESI ZNU. In the context of restructuring, the strategic goal of the EESI ZNU is to restore strategic positions in the market of educational services of engineering profile and integration of management and economic education in the training of specialists for industrial regions of South - Eastern Ukraine. 


\section{Conclusions and recommendations for further researches.}

Thus, modern education is developing in different directions. In our opinion, the national system of higher education is characterized by such fundamental features as humanization (orientation of the educational system and the educational process on the development and formation of mutual respect between students and teachers, based on respect for human rights; preservation and strengthening of their health, self-esteem and development of personal potential); diversity (creation in the educational system of conditions for choosing and giving each subject a chance to succeed, encouraging students to make independent choices and make responsible decisions, ensuring the development of alternative and independent thinking); fundamentalization (strengthening the relationship between theoretical and practical training of young people for modern life through the development of dual education, non-formal and informal education).

The vector of sustainable development of economic and managerial education at the EESI ZNU needs further improvement in the areas of:

- integration into the European Higher Education Space and the European Research Space, which will promote the mobility and employment of citizens, as well as the development of the continent in general;

- adaptation of higher education and research systems in accordance with the needs and requirements of stable, peaceful and democratic societies and the development of scientific knowledge;

- promoting academic mobility by removing obstacles to the effective exercise of the right to free movement of students.

The development of higher education in Ukraine must be subject to the laws of a market economy, and the national higher education system is designed to educate the citizen of Ukraine as a harmoniously developed individual, for whom the need for basic knowledge and general and professional level is associated with strengthening their State.

\section{Author details (in Russian) \\ ЕВРОПЕЙСКИЙ ВЕКТОР УСТОЙЧИВОГО РАЗВИТИЯ ЭКОНОМИЧЕСКОГО И УПРАВЛЫНЧЕСКОГО ОБРАЗОВАНИЯ В ИНЖЕНЕРНОМ ИНСТИТУТЕ В УСЛОВИЯХ РЕСТРУКТУРИЗАЦИИ}

\author{
Наталья Метеленко \\ Запорожский национальный университет \\ пр. Соборный, 22б, г. Запорожье, 69606, Украина \\ e-mail: natalia.metelenko@gmail.com \\ ORCID ID: https://orcid.org/0000-0002-6757-3124
}

\author{
Елена Трохимец \\ Классический частный университет \\ ул. Жуковского, 70б, г. Запорожье, 69602, Украина \\ e-mail:yelena.trohim@gmail.com \\ ORCID ID: https://orcid.org/0000-0001-7587-7948
}

Аннотация. Исследование основывается на реалиях состояния и перспективах развития национальной системы высшего образования в период активных интеграционных процессов в Европейское пространство высшего образования и Европейское исследовательское пространство. Осуществлен анализ отдельных аспектов современного состояния украинской системы образования, определены действия МОН Украины по развитию сотрудничества с международными 
организациями в различных направлениях, в частности, в направлении содействия развитию инновационной деятельности и предпринимательства в Украине, что является особенно актуальным для промышленного региона - Запорожской области, в котором сконцентрированы такие стратегические отрасли экономики Украины, как металлургия, машиностроение, электроэнергетика.

Подчеркивается, что законодательство Украины об образовании ставит такую цель - развитие, эффективное функционирование системы обеспечения качества образования в Украине, осуществление постоянного и последовательного процесса повышения качества образования и отмечается, что стратегия развития Запорожского национального университета заключается в том, чтобы к 2022 году развить и закрепить лидирующие позищии, направленные на подготовку высококвалифицированных специалистов, развитие научных исследований, повышение роли инновационной компоненты в деятельности ЗНУ и его интеграции в европейское и мировое образовательное пространство. Доказано, что реструктуризация учреждений высшего образования в Украине, способствует повышению эффективности их функционирования. Проанализированы изменения, произошедшие в процессе присоединения Запорожской государственной инженерной академии (далее ЗГИА) 8 Запорожский национальный университет (далее ЗНУ) и в результате создания структурного подразделения - Инженерный учебно-научный институт (далее ИУНИ), который имеет безфакультетськую структуру и состоит из пятнадцати кафедр различных направлений подготовки.

В статье обоснованы стратегические преимущества проекта присоединения ЗГИА к ЗНУ, которые позволили диверсифицировать образовательные программы образовательных уровней подготовки бакалавров и магистров специальностей экономического и управленческого направлений с целью современного обновления учебных планов и в дальнейшем подготовки высококвалифицированных специалистов для промышленных регионов, в частности для промышленных предприятий металлургической отрасли, области машиностроения, электроэнергетики $u$ предприятий малого и среднего бизнеса, обслуживающих «большие» предприятия промышленности региона. Проанализированы результаты работы по повышению качества высшего образования в ИУНИ ЗНУ по направлениям развития неформального и информального образования, академической мобильности, дуального образования, создания уникальных условий обучения для льготных категорий студентов $и$ студентов с особыми потребностями, дальнейшей интеграции экономического $и$ управленческого образования в инженерное образование.

Ключевые слова: инженерный учебно-научный институт, университет, академическая мобильность, неформальное образование, информальное образование, европейское образовательное пространство.

\section{Author details (in Ukrainian) ЄВРОПЕЙСЬКИЙ ВЕКТОРСТАЛОГО РОЗВИТКУ ЕКОНОМІЧНОЇ ТА УПРАВЛІНСЬКОЇ ОСВІТИ В ІНЖЕНЕРНОМУ ІНСТИТУТІ В УМОВАХ РЕСТРУКТУРИЗАЦІї}




\section{Наталя Метеленко}

Запорізький національний університет пр. Соборний, 22б, м. Запоріжжя, 69606, Україна e-mail: natalia.metelenko@gmail.com

ORCID ID: https://orcid.org/0000-0002-6757-3124

\section{Олена Трохимець}

Класичний приватний університет

вул. Жуковського, 70б, м. Запоріжжя, 69602, Україна e-mail: yelena.trohim@gmail.com

ORCID ID: https://orcid.org/0000-0001-7587-7948

Анотація. Дослідження грунтується на реаліях стану і перспективах розвитку національної системи вищої освіти в період активних інтеграційних процесів $у$ Європейський простір вищої освіти та Європейський дослідницький простір. Здійснено аналіз окремих аспектів сучасного стану української системи освіти, окреслено дії МОН України щодо розвитку співпраці з міжнародними організаціями у різних напрямах, зокрема, у напряму сприяння розвитку інноваційної діяльності та підприємництва в Україні, що є особливо актуальним для промислового регіону - Запорізької області, в якому сконцентровано такі стратегічні галузі економіки України, як металургія, машинобудування, електроенергетика.

Наголошується на тому, що законодавство України про освіту має на меті розбудову, ефективне функціонування системи забезпечення якості освіти в Україні, здійснення постійного та послідовного процесу підвищення якості освіти та зазначається, що стратегія розвитку Запорізького національного університету (далі ЗНУ) полягає в тому, щоб до 2022 року розвинути та закріпити провідні позиції, спрямовані на підготовку висококваліфікованих фахівців, розвиток наукових досліджень, посилення ролі інноваційного складника у діяльності ЗнУ та його інтеграції до європейського і світового освітнього простору. Доведено, що реструктуризація закладів вищої освіти в Україні, сприяє підвищенню ефективності їх функціонування. Проаналізовано зміни, що відбулись у процесі приєднання Запорізької державної інженерної академії (далі - ЗДІА) до ЗНУ та в результаті створення структурного підрозділу - Інженерний навчально-науковий інститут (далі - IHнI), який має безфакультетську структуру та складається з п'ятнадияти кафедр різних спрямувань підготовки.

У статті обгрунтовано стратегічні переваги проєкту приєднання ЗДІА до ЗНУ, що дозволили диверсифікувати освітні програми освітніх рівнів підготовки бакалаврів та магістрів спеціальностей економічного та управлінського напрямів з метою сучасного оновлення навчальних планів та у подальшому підготовки висококваліфікованих фахівців для промислових регіонів, зокрема для промислових підприємств металургійної галузі, галузі машинобудування, електроенергетики та підприємств малого і середнього бізнесу, що обслуговують «великі» підприємства промисловості регіону. Проаналізовано результати роботи з підвищення якості вищої освіти в ІННІ ЗНУ у напрямах розвитку неформальної та інформальної освіти, академічної мобільності, дуальної освіти, створення унікальних умов навчання для пільгових категорій студентів та студентів з особливими потребами, подальшої інтеграції економічної та управлінської освіти в інженерну освіту.

Ключові слова: інженерний навчально-науковий інститут, університет, академічна мобільність, неформальна освіта, інформальна освіта, європейський освітній простір.

\section{Appendix A. Supplementary material}

Supplementary data associated with this article can be found, in the online version, at http://sepd.tntu.edu.ua/images/stories/pdf/2020/20mngcor.pdf 


\section{Funding}

The authors received no direct funding for this research.

\section{Citation information}

Metelenko, N. \& Trokhymets 0. (2020) European vector of sustainable development of economic and management education in the institute of engineering in the conditions of restructuring. Sotsialno-ekonomichni problemy $i$ derzhava [Socio-Economic Problems and the State] (electronic journal), Vol.22, no.1, pp.3-15. Available at: http://sepd.tntu.edu.ua/images/stories/pdf/2020/20mngcor.pdf

\section{References}

1. (2014) Zakon Ukrainy «Pro vyshchu osvitu» [The Law of Ukraine "On Higher Education"] No 1556-VII, date 01.07.2014 zi zm. ta dop. Rerieved from: https://data.rada.gov.ua/laws/show/1556-18\#Text (Accessed 17.06.2020).

2. Kultura pidpryiemnytstva i innovatsii - MON ukralo memorandum iz UNIT.City. [Culture of Entrepreneurship and Innovation - The Ministry of Education and Science stole a memorandum from UNIT.City.] Rerieved from: https://mon.gov.ua/ua/news/kulturapidpriyemnictva-ta-innovacij-mon-uklalo-memorandum-iz-unitcity

(Accessed 17.06.2020).

3. Stratehiia rozvytku Zaporizkoho natsionalnoho universytetu na 2018 - 2022 roky. [Development strategy of Zaporizhzhia National University for 2018 - 2022] Retrieved from: https://www.znu.edu.ua/docs/2019/ strateg_ya_rozvitku_znu.pdf (Accessed 17.06.2020).

4. Promyslovyi menedzhment: teoriia i praktyka: kolektyvna monohrafiia [Industrial management: theory and practice: a collective monograph] (2020)/ za red. d. filos. n., prof. V. H. Voronkovoi, d. e. n., prof. N. H. Metelenko. Zaporizhzhia: Zaporizkyi natsionalnyi universytet. $338 \mathrm{p}$.

5. Andrushkiv B. M. (2020) Upravlinnia ekonomichnoiu kafedroiu u tekhnichnomu VUZi [Management of the Department of Economics in the Technical University]. Ternopil: FOP Palianytsia V.A. 253 P. 